\title{
Expression of Reg and cytokeratin 20 during ductal cell differentiation and proliferation in a mouse model of autoimmune diabetes
}

\author{
Emanuela Anastasi ${ }^{1}$, Eleonora Ponte ${ }^{2}$, Roberto Gradini ${ }^{3}$, Angela Bulotta $^{1}$, Patrizio Sale ${ }^{3}$, Claudio Tiberti ${ }^{1}$, \\ Hiroshi Okamoto ${ }^{1}$, Francesco Dotta ${ }^{1}$ and Umberto Di Mario ${ }^{1}$ \\ ${ }^{1}$ Endocrinology, Clinica Medica 2, University of Rome 'La Sapienza', Italy, ${ }^{2}$ Experimental Surgery Institute, University of Rome 'Sacro Cuore', Italy, \\ ${ }^{3}$ Experimental Medicine, University of Rome 'La Sapienza', Italy, and Department of Biochemistry, Tohoku University School of Medicine, Sendai, Japan \\ (Correspondence should be addressed to E Anastasi, DEM Foundation, Largo Marchiafava, 1, 00161 Rome, Italy; Email: eanastasi@uniroma1.it)
}

\begin{abstract}
Objective: To evaluate the existence of beta-cell differentiation and proliferation in the low-dose streptozotocin (ld-STZ) mouse model of autoimmune diabetes.

Design: We studied the expression of Reg protein and cytokeratin 20 (CK20), the presence of proliferative phenomena (judged by the incorporation of bromodeoxyuridine (BrdU)), and the co-expression of Reg, CK20 or BrdU with insulin.

Materials and methods: Diabetes was induced in male C57Bl6/J mice by administration of ld-STZ. The animals were killed at days 10 and 23 from the beginning of the induction of disease. Five animals were used at each time point and each group was evaluated for blood glucose concentrations, insulitis, expression of Reg and CK20 pancreatic proteins and BrdU incorporation, together with staining for insulin by immunohistochemistry and laser confocal microscopy.

Results: All mice treated with ld-STZ were hyperglycemic and histological investigation showed a mild or severe insulitis both at day 10 and at day 23. At day 10, immunochemistry revealed an intense expression of Reg and CK2O in pancreatic ducts in ld-STZ mice, but not in control mice. Reg and CK20 immunoreactive cells were also positive for insulin. In contrast, at day 23, pancreatic sections reacted weakly with anti-Reg and anti-CK20 antibody; co-localization with insulin was observed for both Reg and CK20. The incorporation of BrdU was observed only in insulin-positive cells in pancreatic sections from mice killed at day 10.

Conclusions: These observations show an islet regeneration mechanism in response to an autoimmune attack, and that the ld-STZ mouse is a suitable model in which to evaluate intervention strategies.
\end{abstract}

European Journal of Endocrinology $141644-652$

\section{Introduction}

It has been demonstrated that, in embryonic life, pancreatic endocrine cells differentiate mostly from precursor cells located in ductal epithelium, a process called neogenesis (1). In adult life, a low rate of beta-cell replication is sufficient to maintain a constant betacell number and the islet growth results largely from the replication of differentiated islet cells (2). Nevertheless, beta-cell neogenesis in the adult pancreas has been shown to occur in some conditions, including partial pancreatectomy, duct ligation and betacell destruction with toxins, and in animal models of autoimmune diabetes such as non-obese diabetic (NOD), and interferon gamma (IFN- $\gamma$ ) transgenic mice $(3-6)$.

The administration of nicotinamide to $90 \%$ depancreatized rats induces pancreatic islet regeneration (7).
In the same model, screening of an islet-derived cDNA library identified a gene, called reg gene, that encodes a 165-amino acid protein with a 21-amino acid signal peptide (8). Reg gene expression was observed in regenerating pancreatic islets from depancreatized rats, but not in normal ones. Subsequent studies have demonstrated that enhanced reg gene expression is linked to DNA synthesis in pancreatic islets $(9,10)$. Immunocytochemistry has revealed that Reg protein is synthesized in and secreted from the regenerating beta cells and that its expression is closely associated with the regeneration of beta cells (11).

Cytokeratins (CKs), immunocytochemical markers of epithelial cells, are tissue-type specific $(12,13)$. In particular, CK20 is expressed in ductal epithelium and in the peripheral mantle region of neonatal rat islets (14). It has been reported that CK20, when co-expressed with insulin, represents a useful marker 
for the differentiation of ductal cell into endocrine cells (15).

In animal models of autoimmune diabetes, such as NOD mice, alfa cell neogenesis has been reported as a result of ductal epithelial proliferation and differentiation (16).

Autoimmune diabetes may be induced in genetically susceptible mice by administration of multiple low doses of streptozotocin (ld-STZ). The ld-STZ mouse could represent a useful model for the study of beta-cell differentiation and regeneration, because it is possible to program the time of onset of diabetes and the appearance of islet damage, and to follow the various phases of evolution of the disease (17).

In order to evaluate the existence of beta-cell regeneration in a model of autoimmune diabetes, we investigated the differentiation of ductal cells into insulin-producing cells in the ld-STZ model. For this purpose, we evaluated the expression of Reg protein and CK20 and their co-localization with insulin, by double immunohistochemistry and laser confocal microscopy analysis. In addition, the proliferation of insulin positive cells was evaluated. The incorporation of bromodeoxyuridine (BrdU), a thymidine analog normally incorporated into new DNA, was used as a marker for cell replication $(18,19)$. BrdU and insulin double-positive cells were detected by double immunohistochemistry and laser confocal microscopy analysis. Different time points of the disease were investigated in order to define whether the observed effects were related to different stages of the islet destructive process.

\section{Materials and methods}

\section{Animals}

Twenty male $\mathrm{C} 57 \mathrm{Bl} 6 / \mathrm{J}$ mice, aged 6-9 weeks, were used. Diabetes was induced by i.p. administration of STZ ( $40 \mathrm{mg} / \mathrm{kg}$ body weight) daily in citrate buffer for five consecutive days. Animals were killed at two intervals from the beginning of the STZ treatment: at day 10 and at day 23. Five animals were used for each time point investigated, and control mice were included at each time point.

\section{Blood analysis}

Blood samples were obtained from the tail of nonfasting mice using heparinized hematocrit capillary tubes; plasma glucose values were determined by the hexokinase method using an automatic analyzer, and expressed as mmol/l.

\section{Administration of BrdU}

Mice were injected i.p. with a single dose of BrdU $(100 \mu \mathrm{g} / \mathrm{g}$ body weight) dissolved in $0.007 \mathrm{~N} \mathrm{NaOH}$ in normal saline and killed $12 \mathrm{~h}$ after administration of BrdU.

\section{Immunohistochemistry}

Pancreata were removed, snap-frozen in dry ice-cooled isopentane and stored at $-80^{\circ} \mathrm{C}$ for histological studies. Cryostat sections ( $5 \mu \mathrm{m}$ thick) were cut from each pancreas at a distance of $60 \mu \mathrm{m}$ from each other; two slides holding five serial sections were investigated.

Insulitis was investigated by staining with hematoxylin-eosin and scored as follows: none =normal islet histology; mild $=$ minimal cellular infiltrate in the islets; severe $=$ extensive cellular infiltrate into the islet, with loss of the normal architecture.

Consecutive sections were immunostained for Reg or CK20, followed by staining for insulin using the indirect immunofluorescence technique, and studied by laser confocal microscopy (Zeiss LSM 310). All antibody incubations were for $1 \mathrm{~h}$ at room temperature, followed by two washings in PBS. The primary antibodies used were mouse anti-rat Reg monoclonal antibody, diluted 1 : 500; mouse anti-human CK20 monoclonal antibody, diluted 1:25 (Clone Ks 20.8; Dako, Copenhagen, Denmark); and guinea pig anti-insulin polyclonal antibody (Dako), diluted 1:50. All antibodies were diluted in PBS pH 7.5, $0.15 \mathrm{~mol} / \mathrm{l} \mathrm{NaCl}$.

The secondary antibodies were Texas-Red goat anti-mouse IgG (Calbiochem San Diego, CA, USA) for the detection of Reg and CK20, and fluorescein isothiocyanate-conjugated rabbit anti-guinea pig IgG (Dako) for insulin detection.

In order to evaluate insulin and BrdU double-positive cells, sections were first incubated with the polyclonal antibody to insulin and revealed with the secondary fluoresceinated antibody, followed by DNA denaturation with $2 \mathrm{~N} \mathrm{HCl}$ for $30 \mathrm{~min}$ at $37^{\circ} \mathrm{C}$. Afterwards, sections were incubated with an anti-BrdU mouse monoclonal antibody, diluted 1:20 (Clone Bu20a; Dako) followed by Texas-Red-conjugated anti-mouse IgG. Slides were mounted in fluorescent mounting medium and stored in the dark. Sections were analyzed by confocal laser microscopy.

\section{Statistical analysis}

Values are expressed as mean \pm s.E.M. The significance of differences in blood glucose concentrations was assessed by the Mann-Whitney $U$ test.

\section{Results}

\section{Blood glucose concentrations and body weight}

At day 10, blood glucose concentrations were $19.46 \pm$ $1.8 \mathrm{mmol} / \mathrm{l}$ (mean \pm s.E.M.) in ld-STZ-treated mice and $8.24 \pm 0.34 \mathrm{mmol} / \mathrm{l}$ in control mice, whereas body 
weights were $20.2 \pm 1.0 \mathrm{~g}$ and $23.4 \pm 1.5 \mathrm{~g}$, respectively. At day 23, glycemic values were 18.24 \pm $2.2 \mathrm{mmol} / \mathrm{l}$ in STZ mice and $7.94 \pm 1.4 \mathrm{mmol} / \mathrm{l}$ in untreated animals, whereas body weights were $20.6 \pm 2.0 \mathrm{~g}$ and $24.0 \pm 1.5 \mathrm{~g}$, respectively. Both at day 10 and at day 23, all STZ-treated animals showed blood glucose concentrations above the normal range and significantly greater than those in control mice (ld-STZ 12 and ld-STZ 24 vs control mice; $P<0.01$ ), and a body weight lower than that of the control mice (ld-STZ 12 vs control mice; $P<0.02$; ld-STZ 24 vs control mice; $P<0.01$ ).

\section{Islet and pancreas histology}

Insulitis At day 10, islets from mice treated with STZ showed $6.5 \%$ of islets without lymphocyte infiltration, $69.8 \%$ of islets with a mild grade of insulitis and $23.7 \%$ of islets with a severe grade of insulitis (Fig. 1a). At day 23 , we observed $1.4 \%$ of islets with normal architecture without evidence of insulitis, $62.8 \%$ of islets with a mild insulitis and $35.8 \%$ of islets with a severe grade of insulitis (Fig. 1b). No lymphocytic infiltration was observed in control animals.

Expression of Reg protein In ld-STZ animals, at day 10 , the expression pattern of Reg revealed that anti-Reg antibodies reacted intensively with pancreatic ducts (Fig. $2 a$, red) and cell clusters (Fig. 3a, red). These results were observed in all the animals killed on day 10 . The same sections showed insulin immunoreactivity (Figs $2 b$ and $3 b$; green), as evidence that Reg protein is expressed in insulin-producing cells (Figs $2 c$ and $3 c$; blue). At day 23, the expression pattern of Reg, similar in all the animals killed, showed a weak reaction with anti-Reg antibodies (Fig. 4a, red). The same sections showed weak insulin immunoreactivity (Fig. 4b, green) and Reg-immunoreactive cells showed insulin immunoreactivity (Fig. $4 c$, blue).

In normal mice, double positivity for Reg and insulin was not detected.

Expression of CK20 In ld-STZ mice, at day 10, the distribution pattern of CK20 revealed that anti-CK20 antibody reacted intensively with ducts and ductules, but not with islets (Fig. $5 a$, red). The same results were obtained in all the mice killed at day 10. The same section showed an intense staining for insulin (Fig $5 b$, green). CK20-positive cells showed co-staining with insulin, demonstrating that CK20 protein is expressed in insulin-producing cells (Fig. $5 c$, blue). At day 23, the staining of anti-CK20 and insulin antibodies was weak (Fig. 6a, red; Fig. $6 b$, green) in all the mice killed, and the CK20-immunoreactive cells showed co-localization with insulin (Fig. 6c, blue).

In normal mice, double positivity for CK20 and insulin was not revealed.
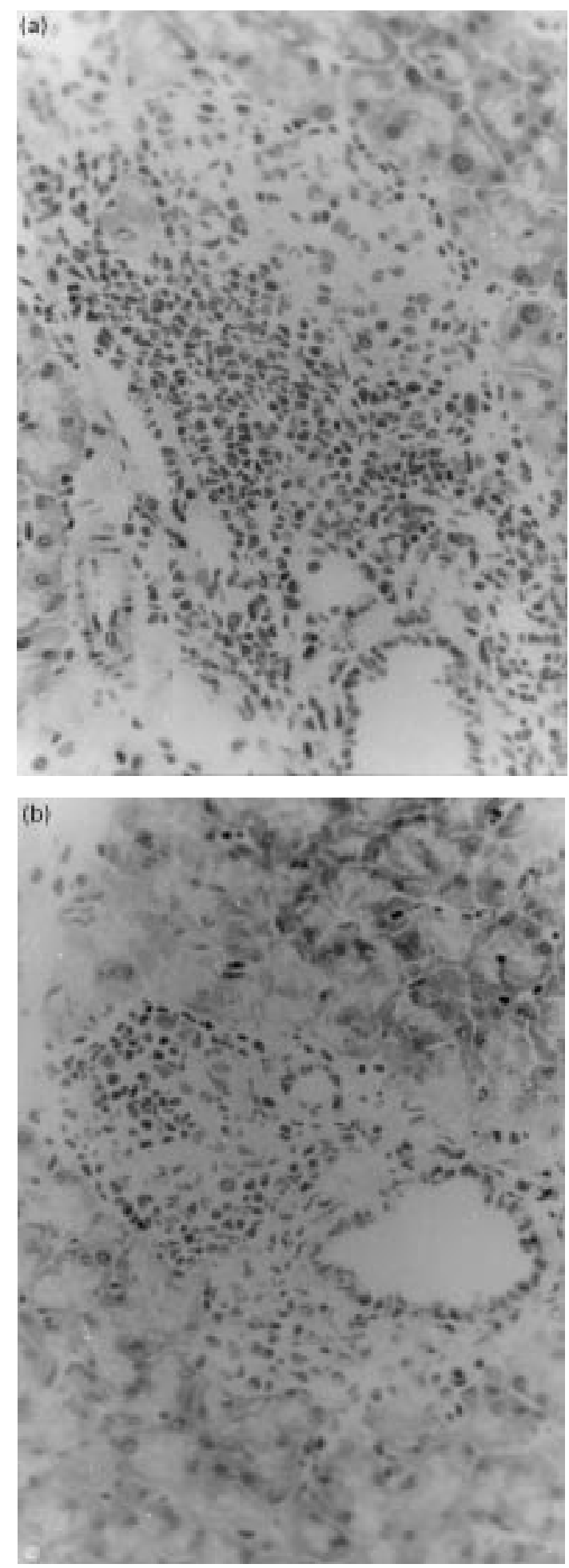

Figure 1 Light micrograph of hematoxylin and eosin-stained pancreatic islets from Id-STZ-treated mice on day 10 (a) and day 23 (b) from the beginning of STZ treatment. Histological analysis showed the presence of insulitis at both days 10 and 23 . 

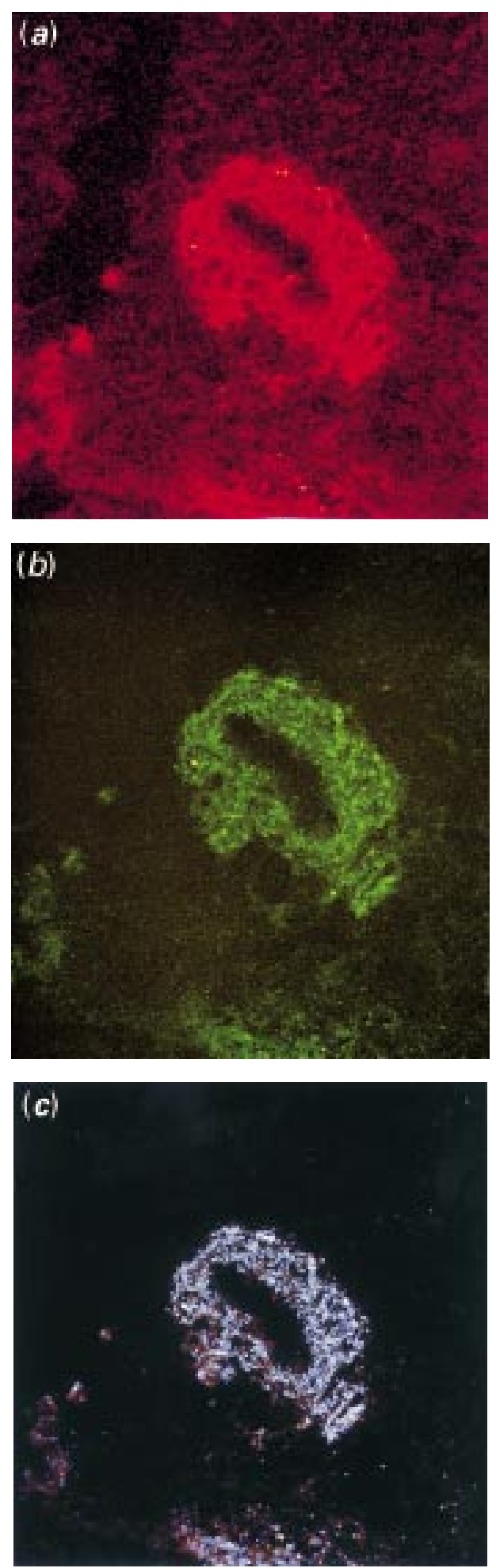

Figure 2 Double immunofluorescence, followed by laser confocal microscopy, performed on sections ( $5 \mu \mathrm{m}$ thick) from ld-STZ mouse pancreas at day 10 from the beginning of STZ administration. This figure shows a large duct expressing Reg $(a$, red) and insulin (b, green). The co-localization of Reg and insulin is highlighted by the blue color (c).
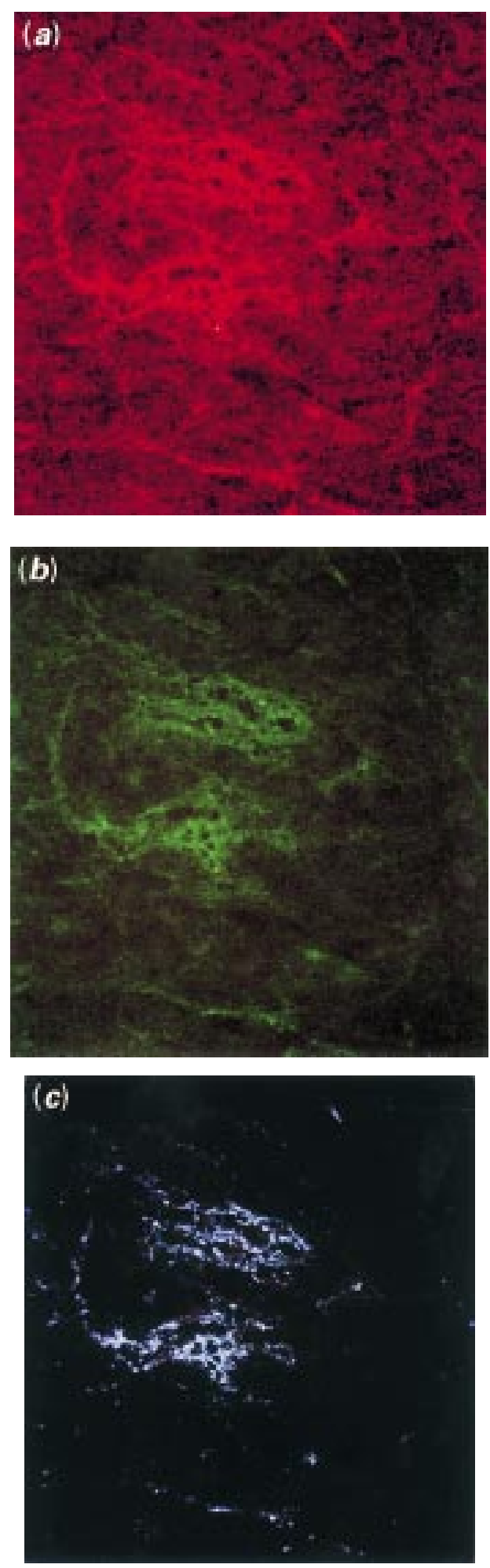

Figure 3 Double immunofluorescence, followed by laser confocal microscopy, performed on sections ( $5 \mu \mathrm{m}$ thick) from Id-STZ mouse pancreas at day 10 from the beginning of STZ

administration. This figure shows cells expressing Reg (a, red) and insulin ( $b$, green). The co-localization of Reg and insulin is highlighted by the blue color $(c)$. 

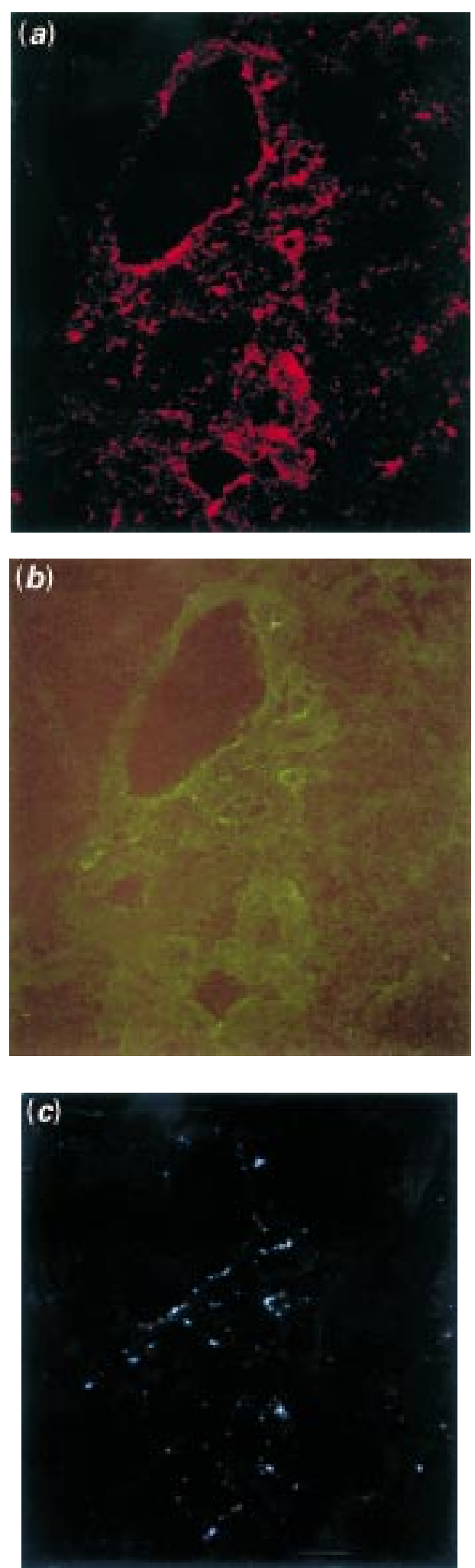

Figure 4 Double immunofluorescence, followed by laser confocal microscopy, performed on sections ( $5 \mu \mathrm{m}$ thick) from ld-STZ mouse pancreas at day 23 from the beginning of STZ administration. This figure shows some ducts weakly expressing Reg ( $a$, red) and insulin (b, green). The co-localization of Reg and insulin is highlighted by the blue color $(c)$.
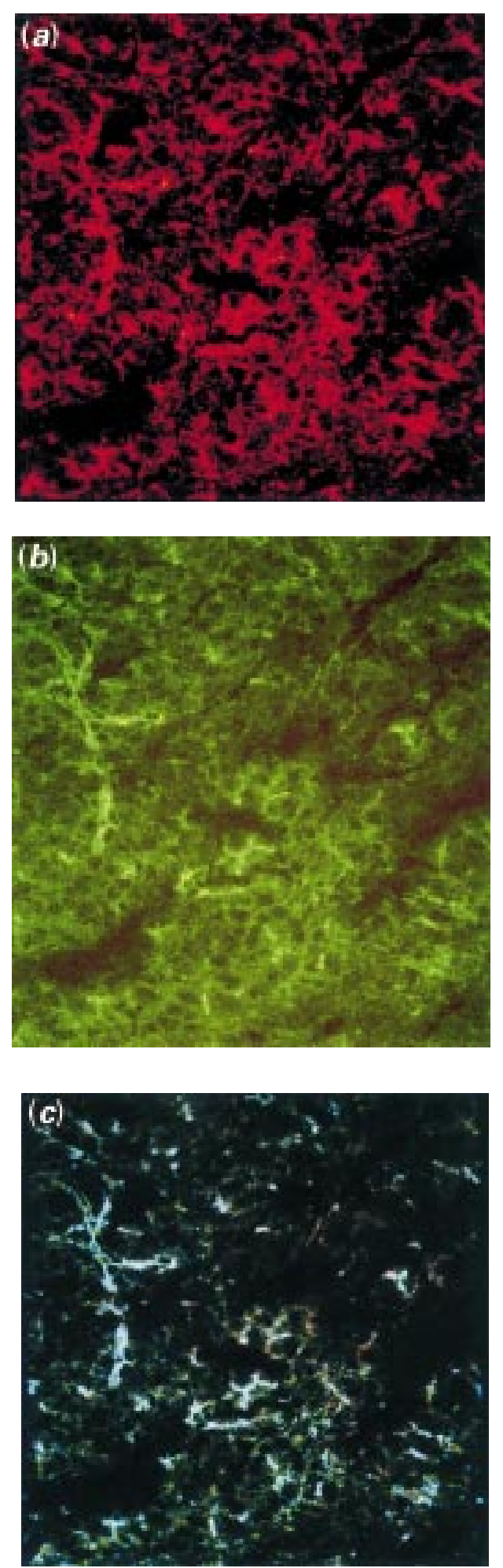

Figure 5 Double immunofluorescence, followed by laser confocal microscopy, performed on sections ( $5 \mu \mathrm{m}$ thick) from Id-STZ mouse pancreas at day 10 from the beginning of STZ

administration. This figure shows some ductules expressing CK20 ( $a$, red) and insulin ( $b$, green). The co-localization of CK20 and insulin is highlighted by the blue color $(c)$. 

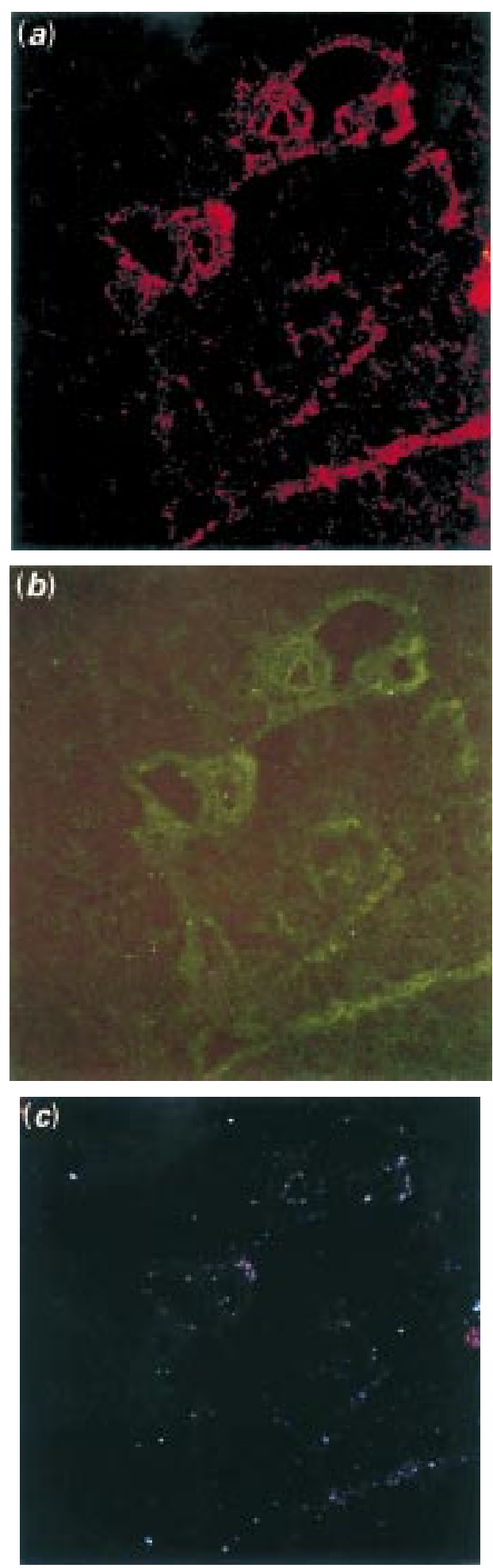

Figure 6 Double immunofluorescence, followed by laser confocal microscopy, performed on sections ( $5 \mu \mathrm{m}$ thick) from Id-STZ mouse pancreas at day 23 from the beginning of STZ

administration. This figure shows some ducts faintly expressing CK20 ( $a$, red) and insulin ( $b$, green). The co-localization of CK20 and insulin is highlighted by the blue color $(c)$.
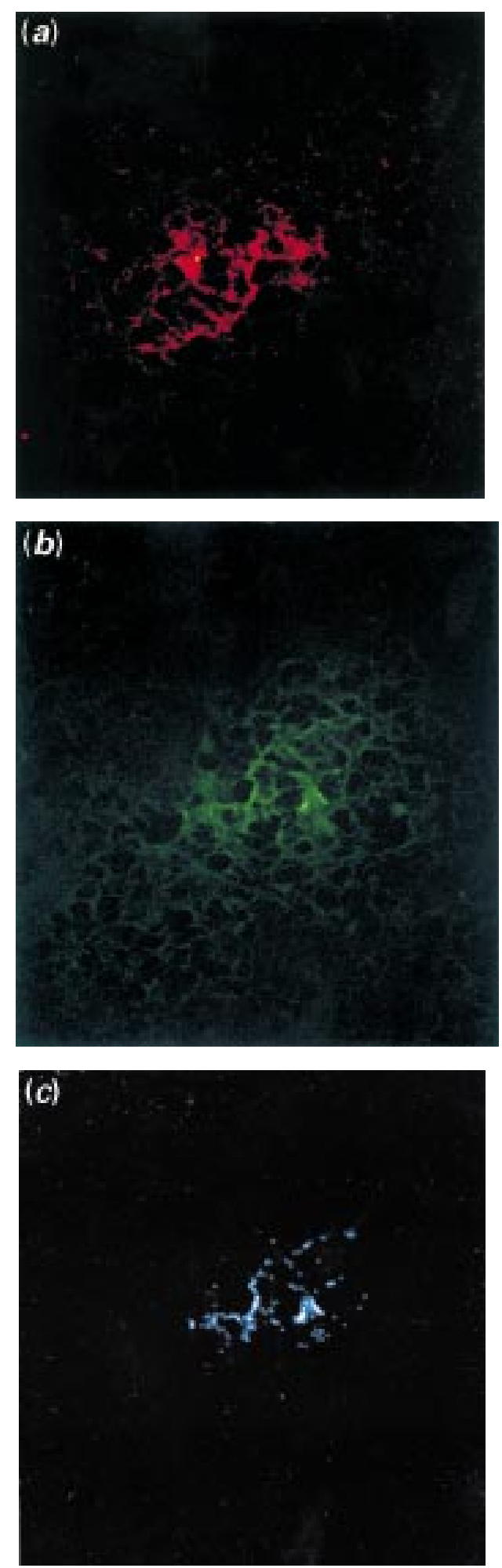

Figure 7 Double immunofluorescence, followed by laser confocal microscopy, performed on sections $(5 \mu \mathrm{m}$ thick) from Id-STZ mouse pancreas at day 10 from the beginning of STZ administration. This figure shows $\mathrm{BrdU}$ incorporation ( $a$, red) and insulin expression ( $b$, green). The co-localization of BrdU and insulin is highlighted by the blue color (c). 

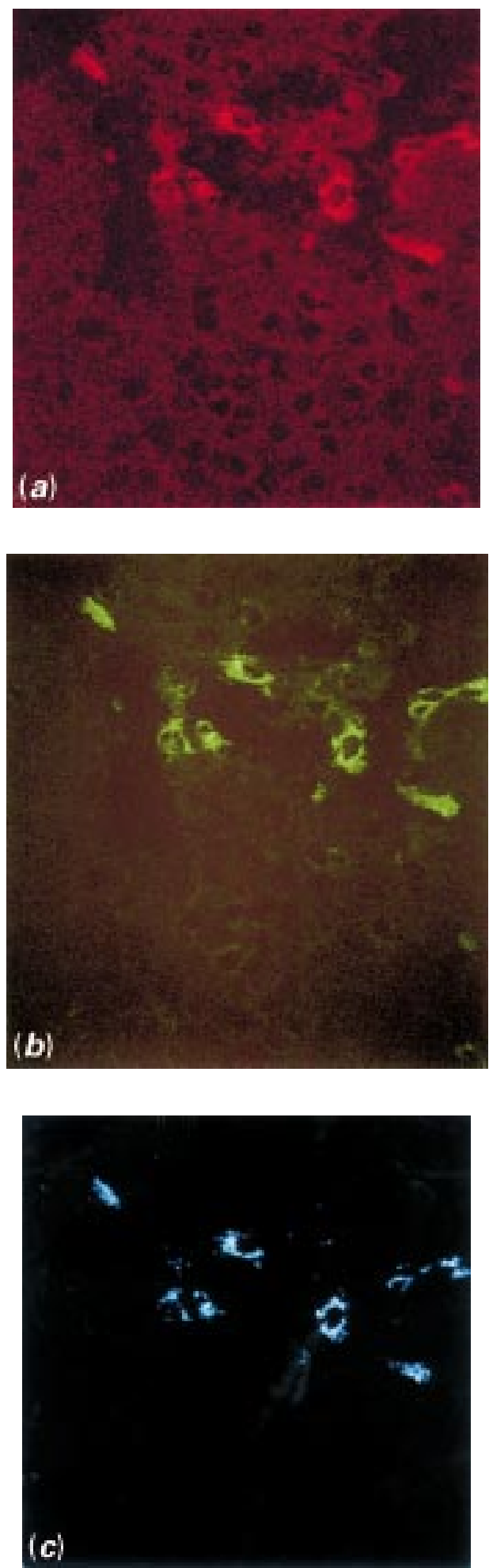

Figure 8 Double immunofluorescence, followed by laser confocal microscopy, performed on sections ( $5 \mu \mathrm{m}$ thick) from Id-STZ mouse pancreas at day 10 from the beginning of STZ administration. This figure shows $\mathrm{BrdU}$ incorporation ( $a$, red) and insulin expression ( $b$, green). The co-localization of BrdU and insulin is highlighted by the blue color $(c)$.
BrdU Iabeling In the ld-STZ mice, at day 10, the incorporation pattern of BrdU showed that a number of BrdU-positive cells were present in pancreatic sections (Figs $7 a$ and $8 a$; red). These results were observed in all the animals killed at day 10 . The same section was stained for insulin (Fig. $7 b$ and $8 b$; green). Among the BrdU-positive cells, some showed co-staining with insulin antibodies (Figs $7 c$ and $8 c$; blue).

At day 23, all sections investigated failed to demonstrate BrdU incorporation.

In normal mice, the incorporation of BrdU into pancreatic islets was not observed.

\section{Discussion}

In this study, we have demonstrated that differentiation and proliferation of insulin-producing cells are detectable in pancreatic ducts and ductules in the early phases of the islet destructive process in a model of autoimmune diabetes, the low-dose streptozotocin (ld-STZ) mouse.

All mice treated with ld-STZ remained hyperglycemic throughout the study. At day 10, Reg- CK20- or BrdUpositive cells were insulin immunoreactive, reflecting differentiation and proliferation of beta cells from ducts and ductules. The existence of a regenerating process in the early stages of autoimmune damage, but not later, suggests that factors released during the early damaging process may trigger the precursor/stem cells that induce islet regeneration events $(20,21)$.

Our findings demonstrated the expression of Reg protein and its co-localization with insulin in ductal cells in the early stages of the disease. This suggests that this protein is strongly associated with beta-cell neogenesis. The expression of Reg protein in a model of autoimmune diabetes, the ld-STZ mouse, is in agreement with recent findings, in NOD mice and BB rats, of a significant increase in Reg mRNA expression during active diabetogenesis $(22,23)$. In addition, a recent study has shown that the administration of recombinant rat Reg protein is able to stimulate the regeneration of beta cells (24).

As far as the expression of CK20 is concerned, we observed a co-localization with insulin, thus confirming the existence of transitional cytodifferentiation forms between ductal and islet endocrine cells. In accordance with other investigators, we have observed a transitory expression of CK20 in duct beta cells of diabetic mice, suggesting that its expression may represent a final step in the differentiation pathway (15). The double positivity for Reg or CK20 with insulin in the ductal cells also confirms the hypothesis that the pancreatic stem cells responsible for islet cell neoformation appear to be located in the ductal compartment (25).

Our study showed BrdU-insulin double-positive cells in different sections from the same portions of pancreata in which Reg- and CK20-positive cells had already been detected. This observation demonstrates 
the existence of active proliferation of insulin-positive cells in those same pancreata in which phenomena indicative of beta-cell neogenesis are present.

The observation of early, but not late, regenerating process in our animal model may reflect the progression of autoimmune damage, the lack of a growth factor appropriate to prolonged beta-cell proliferation, or both. This last point is reinforced by a recent report that, in transgenic mice overexpressing gastrin and transforming growth factor $\alpha$ (TGF $\alpha)$, islet neogenesis can be reactivated in the ductular epithelium by local expression of the two growth factors, gastrin and TGF $\alpha(26,27)$.

It is current opinion that beta-cell neogenesis occurs only after deletion of most of the original population of mature beta cells (28). In contrast, in our study, we have demonstrated beta-cell differentiation and proliferation in the early stages of damage, which may suggest an attempt to restore the number of beta cells killed by the autoimmune attack.

In conclusion, this study represents a direct demonstration of ductal beta-cell differentiation and proliferation in an autoimmune model of diabetes, the ld-STZ mouse. Moreover, Reg protein is demonstrated to be a useful marker for the evaluation of beta-cell neogenesis. In addition, the co-expression of CK20 with insulin in ductal cells is confirmed as a marker of ductal differentiation into endocrine cells. Preventive or therapeutic strategies aimed at the regeneration of beta cells through the enhancement of the mechanisms involved in beta-cell growth and differentiation should be tested in this model.

\section{Acknowledgements}

This study was supported by grants from the Italian National Research Council (CNR, progetto singolo grant no. 95.04360.CT04 holder Dr E Anastasi), the Centro Internazionale Studi Diabete (CISD) and Diabetes, Endocrinology, Metabolism (DEM Foundation), Rome. Dr R Filippetti and his staff of the Universita' Cattolica del Sacro Cuore, Rome, are kindly acknowledged for animal-house management. The authors are also grateful to Dr R Perfetti for helpful discussion and S Cipriani, $\mathrm{G}$ Romani and P Cerrone for their skilful technical assistance.

\section{References}

1 Logotheopoulos J. Islet regeneration and neogenesis. In Handbook of Physiology. Section 7, Endocrinology, Vol.1 pp 67-76. Eds DF Steiner \& N Freinkel N. Washington: American Physiological Society, 1972.

2 Hellestrom C, Andersson A \& Gunnarsson R. Regeneration of islet cells. Acta Endocrinologica 199683 (Suppl 205) 145-158.

3 Brockenbrough JS, Weir GC \& Bonner-Weir S. Discordance of exocrine and endocrine growth after $90 \%$ pancreatectomy in rats. Diabetes $198837232-236$.
4 Bonner-Weir S, Baxter LA, Schuppin GT \& Smith F. A second pathway for regeneration of adult exocrine and endocrine pancreas: a possible recapitulation of embryonic development. Diabetes 19932 1715-1720.

5 Sarvetnick NE \& Gu D. Regeneration of pancreatic endocrine cells in interferon-gamma transgenic mice. Advances in Experimental Medicine and Biology 1992321 85-89.

6 Wang RN, Klöppel G \& Bouwens L. Duct-to-islet cell differentiation and islet growth in the pancreas of duct-ligated adult rats. Diabetologia 199538 1405-1411.

7 Yonemura Y, Takashima T, Miwa K, Miyazaki I, Yamamoto H \& Okamoto H. Amelioration of diabetes mellitus in partially depancreatised rats by poly(ADP-ribose) synthetase inhibitors. Diabetes 198433 401-404.

8 Terazono K, Yamamoto H, Takasawa S, Shiga K, Yonemura Y, Tochino Y \& Okamoto $\mathrm{H}$. A novel gene activated in regenerating islet. Journal of Biological Chemistry 1988263 21112114.

9 Francis PJ, Southgate JL, Wilkin TJ \& Bone AJ. Expression of an islet regenerating (reg) gene in isolated rat islet: effects of nutrient and non-nutrient growth factors. Diabetologia 1992 $35238-242$.

10 Miyaura C, Ling C \& Appel M. Expression of reg gene/PSP, a pancreatic exocrine gene: relationship to changes in islet betacell mass. Molecular Endocrinology 19915 226-234.

11 Terazono K, Uchiyama Y, Ide M, Watanabe T, Yonekura H, Yamamoto $\mathrm{H}$ \& Okamoto $\mathrm{H}$. Expression of reg protein in rat regenerating islet and its co-localization with insulin in the beta cell secretory granules. Diabetologia 199133 250-252.

12 Moll R, Franke WW \& Schiller DL The catalog of human cytokeratins: patterns of expression in normal epithelia, tumors and cultured cells. Cell 198231 11-24.

13 Franke WW, Jahn L \& Knapp AC Cytokeratins and desmosomal proteins in certain epithelioid and nonepithelial cells. In Cytoskeletal Proteins in Tumor Diagnosis, pp 151-172. Eds M Osborn \& K Webber. Cold Spring Harbor:Cold Spring Harbor Laboratories, 1989.

14 Bouwens L, Wang RN, De Blay E, Pipeleers DG \& Klöppel G. Cytokeratins as markers of ductal cell differentiation and islet neogenesis in the neonatal rat pancreas. Diabetes 199443 1279-1283.

15 Wang RN, Bouwens L \& Klöppel G. Beta-cell growth in adolescent and adult rats treated with streptozotocin during the neonatal period. Diabetologia $199639548-557$.

16 O'Reilly LA, Gu D, Sarvetnick N, Edlund H, Phillips JM, Fulford T \& Cooke A. $\alpha$-Cell neogenesis in an animal model of IDDM. Diabetes 199746 599-606.

17 Like AA \& Rossini AA. Streptozotocin-induced pancreatic insulitis: a new model of diabetes mellitus. Science 1976193 415-417.

$18 \mathrm{Gu}$ D, Lee M, Krahl T \& Sarvrtnick N. Transitional cells in the regenerating pancreas. Development $19941201873-1881$.

19 De Fazio A, Leary JA, Heley DW \& Tattersall MHN Immunohistochemical detection of proliferating cells in vivo. Journal of Histochemistry and Cytochemistry 19875 571-577.

$20 \mathrm{Gu} \mathrm{D} \mathrm{\&} \mathrm{Sarvetnik} \mathrm{N.} \mathrm{Epithelial} \mathrm{cell} \mathrm{proliferation} \mathrm{and} \mathrm{islet}$ neogenesis in IFN-g transgenic mice. Development 1993118 $33-46$.

21 Mosmann TR. Cytokines, is there biological meaning? Current Opinion in Immunology 19913 311-314.

22 Baeza NJ, Moriscot CI, Renaud WP, Okamoto H, Figarella CG \& Vialettes $\mathrm{BH}$. Pancreatic regenerating gene overexpression in the nonobese diabetic mouse during active diabetogenesis. Diabetes $19963367-70$.

23 Bone A, Banister SH \& Zhan S. Islet cell defence and repair mechanisms in insulin-dependent diabetes: a role for the pancreatic regenerating (reg) gene. Biochemistry Society Transactions 199422 37-41.

24 Gross DJ, Weiss L, Reibstein I, van den Brand J, Okamoto H, Clark A \& Slavin S. Amelioration of diabetes in nonobese-diabetic 
mice with advanced disease by linomide-induced immunoregulation combined with Reg protein treatment. Endocrinology $19981392369-2374$.

25 Wang RN, Bouwens L \& Klöppel G. Beta-cell growth in adolescent and adult rats treated with streptozotocin during the neonatal period. Diabetologia $199639548-557$.

26 Wang TC, Bonner-Weir S, Oates PS, Chulak MB Simon B, Merlino GT, Schmidt E \& Brand S. Pancreatic gastrin stimulates islet differentiation of transforming growth factor $\alpha$-induced ductular precursor cells. Journal of Clinical Investigation 199392 1349-1356.
27 Wang RN, Rehfeld JF, Nielsen FC \& Klöppel G. Expression of gastrin and transforming growth factor- $\alpha$ during duct to islet cell differentiation in the pancreas of duct-ligated adult rats. Diabetologia $199740887-893$.

28 Vinik A, Rafaeloff R, Pittenger G, Rosenberg L \& Duguid W. Induction of pancreatic islet neogenesis. Hormone and Metabolic Research 199729 278-293 (Symposium report).

Received 29 March 1999

Accepted 19 July 1999 